EGU21-10178

https://doi.org/10.5194/egusphere-egu21-10178

EGU General Assembly 2021

(c) Author(s) 2021. This work is distributed under

the Creative Commons Attribution 4.0 License.

\title{
From rice-microalgae As removal to electricity generation using a microbial fuel cell: a new conceptual approach for the agro- industrial sector
}

Cristiane Ottoni ${ }^{1,2}$, Patrícia Vidigal ${ }^{2}$, Maria Manuela Abreu², Glória Esquível ${ }^{2}$, Isabel Sousa ${ }^{2}$, and António Brito ${ }^{2}$

${ }^{1}$ São Paulo State University (UNESP), Biosciences Institute, Biology, Brazil (cristiane.ottoni@unesp.br)

${ }^{2}$ Linking Landscape, Environment, Agriculture and Food (LEAF), Instituto Superior de Agronomia (ISA), Universidade de

Lisboa, Lisboa, Portugal

The presence of As in soil and water can be considered a global threat that can potentially contaminate the food chain. Thus, the remediation of these resources and the decrease of As concentration is a major research goal, especially in rice that tends to accumulate As in the grain. Arsenic uptake by plant species depends on As concentration in the available fraction of the soil and speciation. Several agronomic strategies have been tested to decrease As concentration in rice grain. These include water management, nutrient management and biological approaches among others. In this context, microalgae is known to be effective in the uptake and metabolize of potentially toxic elements like As, which is a cost-effective approach compared to other agronomic strategies. However, in the view of the the current global panorama of growing respect for environmental preservation and focus on energy generation from renewable resources (including domestic and industrial waste products), the use of Microbial Fuel Cells (MFC) has been gaining increased attention. The MFCs have enormous potential as they simultaneously promote the treatment of different types of waste and generate electricity. This is possible due to the conversion of the chemical energy available in the biodegradable substrates directly into electricity, through the catalytic action of electrogenic bacteria attached to the anodic electrode. We aim to develop and establish a protocol for biodegradation of As, captured by microalgae grown in paddy rice fields, in compounds less harmful to the environment and at the same time generating electricity in a continuous process. For this purpose, a selection will be made of cathodic-algae, different electrodes and membrane materials, as well as the operating conditions of MFC. The results monitored are chemical oxygen demand, nitrogen, phosphorus, $\mathrm{pH}$, and production of electricity. At the end, we will be able to evaluate the possibility of decreasing rice As uptake by microalgae that will serve as a raw material for the production of electricity. This will contribute both to help achieve the new European Green Deal policy framework linked with the UN 17 Sustainable Development Goals for 2030, by promoting a resource-efficient and competitive agri-economy while guarantying the health and well-being of citizens from environment-related risks and impacts, covering the "farm to fork" food value chain. 